\title{
Lethal disease in infant and juvenile Syrian hamsters experimentally infected with Imjin virus, a newfound crocidurineshrew-borne hantavirus
}

[Running title:Imjin virus infection in Syrian hamsters]

Se Hun Gu ${ }^{\mathrm{a}, \mathrm{b}}$,Young-Sik Kim ${ }^{\mathrm{c}}$, Luck JuBaek ${ }^{\mathrm{a}}$, Takeshi Kurata ${ }^{\mathrm{d}}$, Richard Yanagihara ${ }^{\mathrm{b}}$, Jin-Won Song ${ }^{\mathrm{a}, *}$

${ }^{a}$ Department of Microbiology, College of Medicine, Institute for Viral Diseases, KoreaUniversity, 5-ga, Anam-dong, Seongbuk-gu, Seoul136-705, Korea

${ }^{b}$ Pacific Center for Emerging Infectious Diseases Research, John A. Burns School ofMedicine, University of Hawaii at Manoa, 651 Ilalo Street, Honolulu, HI96813, USA

${ }^{c}$ Department of Pathology, Ansan Hospital, College of Medicine, Korea University, Ansan 425 707, Korea

${ }^{d}$ Department of Pathology, National Institute of Infectious Diseases, Toyama 1-23-1, Shinjuku, Tokyo 162-8640, Japan

\footnotetext{
* Corresponding author at: Department of Microbiology, College of Medicine, Institute for Viral Diseases, Korea University, 5-Ga, Anam-dong, Seongbuk-gu, Seoul136-705, Korea. Tel.: +822920 6408; fax: +8229233645

E-mail: jwsong@korea.ac.kr (J. -W. Song).
}

Key Words: Imjin virus; Syrian hamster;hantavirus;meningoencephalitis 


\section{Introduction}

Rodents (order Rodentia), belonging to the Muridae and Cricetidae families, have long been known to serve as reservoir hosts of hantaviruses (family Bunyaviridae, genus Hantavirus), which are enveloped viruses with a negative-sense, single-stranded, tripartite RNA genome, consisting of large (L), medium (M) and small (S) segments, which encode an RNA-dependent RNA polymerase (RdRp), two envelope glycoproteins ( $\mathrm{Gn}, \mathrm{Gc})$ and a nucleocapsid protein (NP), respectively(Schmaljohn and Dalrymple, 1983; Schmaljohn et al., 1983). Hantaviruses, such as Hantaan virus (HTNV), Seoul virus (SEOV) and Puumala virus (PUUV), which are harbored by murid and arvicolid rodents, cause hemorrhagic fever with renal syndrome (HFRS), an acute febrile disease characterized by varying degrees of hemorrhage and renal insufficiency (Brummer-Korvenkontio et al., 1980; Lee et al., 1978; Lee and Vandergroen, 1989; Yanagihara and Gajdusek, 1988). By contrast, hantaviruses, such as Sin Nombrevirus (SNV), Andes virus (ANDV), Black Creek Canal virus (BCCV) and Choclovirus (CHOV), hosted by neotomine andsigmodontine rodents, cause hantavirus pulmonary syndrome (HPS), which is characterized by rapidly progressive respiratory failure with high mortality (Duchin et al., 1994; Lopez et al., 1996; Nelson et al., 2010; Nichol et al., 1993; Ravkov et al., 1995; Zaki et al., 1995).

More recently, attention has been drawn toward genetically distinct hantavirusesdetected by reverse transcription polymerase chain reaction (RT-PCR) in multiple species of shrews and moles (order Eulipotyphla, familiesSoricidae and Talpidae) and insectivorous bats (order Chiroptera)in widely separated geographic regions across Europe, Asia, Africa and North America (Bennett et al., 2014; Yanagihara et al., 2014). However, of the more than 30 nonrodent-borne hantaviruses, only two have been isolated in cell culture. The first 
is Thottapalayamvirus (TPMV),originally isolated from spleen tissue ofan Asian house shrew (Suncusmurinus)captured in southern India in 1964 (Carey et al., 1971; Song et al., 2007).And the second isImjin virus (MJNV), isolated from lung tissues ofUssuri white-toothed shrews (Crociduralasiura), captured near the demilitarized zone in Korea(Song et al., 2009).

Whether or not soricid-borne hantaviruses infect and cause disease in humans isunknown.In this regard, the paucity ofhantavirus isolates and the lack of animal models for these newfoundhantaviruses, harbored by shrews, moles and bats, has impeded our understanding about their infectivity and pathogenicityin humans. We reasoned that studying the clinical and pathological features of experimental MJNV infection in laboratory animals might indirectly provide insights about MJNV-caused diseases in humans.Moreover, because the Syrian hamster has served as a reliable host for experimental infection with HFRS- and HPScausing hantaviruses, for both the study of HPS pathogenesis and the testing of hantavirus vaccines (Brocato et al., 2014; Chu et al., 1995; Hooper et al., 1999, 2001, 2013; Safronetz et al., 2011, 2012; Sanada et al., 2011; Schmaljohn et al., 1990; Wahl-Jensen et al., 2007), we selected this cricetid rodent species to conduct a proof-of-concept study of experimental MJNV infection. Our results indicate that infant and juvenile Syrian hamsters develop lethal disease, while adulthamsters develop subclinical infection, following intraperitoneal inoculation with MJNV. Such models might provide valuable insights into the persistence and pathogenicity of MJNV and of other still-orphan non-rodent-borne hantaviruses, which have yet to be isolated. 


\section{Materials and Methods}

\subsection{Virus and cell culture}

MJNV strains 04-55 and 05-11, isolated in Vero E6 cells (Vero C1008; CRL 1586, American Type Culture Collection, Manassas, VA) from lung tissues of Ussuri white-toothed shrews captured in Yeoncheon county and Paju city, respectively, in Korea(Song et al., 2009),were propagated in Vero E6 cells, maintained in Dulbecco's modified Eagle's mediumsupplemented with 5\% heat-inactivated fetal bovine serum (Lonza, Walkersville, MD), 2 $\mathrm{mM} \mathrm{L-glutamine}$ and antibiotics (penicillin/streptomycin) at $37^{\circ} \mathrm{C}$ at $5 \% \mathrm{CO}_{2}$. As determined by plaque assay (Song et al., 2009), the infectivity titers of the MJNV stocks were $2 \times 10^{5} \mathrm{pfu} / \mathrm{mL}$.

\subsection{Ethics statement}

All inoculation and handling of rodents, as well as the method of euthanasia andcollection of tissues, were performed according to well-established protocols, approved by the Institutional Animal Care and Use Committee of Korea University.

\subsection{Animals and virus inoculation}

Syrian hamsters (Mesocricetusauratus), designated as "special pathogens free", were purchased from DaehanBiolink Co., Ltd (Chungcheongbuk-do, Korea).Hamsters were divided into seven groups (with five to 10 hamsters per group) according to their postnatal age $(<1,5,10$, $14,21,35$ and 56 days),were inoculated with 1,000pfu of MJNV strains 04-55 and 05-11 by the intraperitoneal route. Hamsters were monitored daily for clinical signs, and were euthanized if moribund or at prescribed time points post-inoculation. Experiments were terminated 42 days 
after inoculation. Isoflurane anesthesia, followed by cardiac puncture,was used for euthanasia. Sera were testedfor immunoglobulin G (IgG) antibodies against MJNV by the indirect immunofluorescent antibody (IFA) test and enzyme-linked immunosorbent assay (ELISA). All animal experiments were performed under ABSL-3 containment, in a facility in which ANDV, SNV and other HPS-causing hantaviruses had never been handled.

\subsection{RNA extraction and RT-PCR}

Total RNA was extracted from 100 mg of tissues (heart, lung, liver, kidney, spleen, intestine and brain), using RNA-Bee ${ }^{\mathrm{TM}}$ (Tel-Test, Inc., Friendswood, TX). Each 20- $\mu$ L reaction contained $10 \mu \mathrm{L}$ total RNA, $2 \mu \mathrm{L}$ random primer $(10 \mu \mathrm{M}), 1 \mu \mathrm{L}$ dNTP (Finnzymes, Vantaa, Finland), $0.5 \mu \mathrm{L}$ RNase inhibitor (Thermo Fisher Scientific. Waltham, MA), $0.5 \mu \mathrm{L}$ Moloney murine leukemia virus (M-MLV) Reverse Transcriptase (Promega, Madison, WI) and $4 \mu \mathrm{LM}$ MLV 5X reaction buffer. The reaction was performed at $37^{\circ} \mathrm{C}$ for $1 \mathrm{hr}$ and $94^{\circ} \mathrm{C}$ for $3 \mathrm{~min}$ for terminal reaction. Gene-amplification reactions were performed in $50-\mu \mathrm{L}$ reaction mixtures, containing $200 \mu \mathrm{MdNTP} \square \square 1.5 \mathrm{mM} \mathrm{MgCl}_{2}, 0.5 \mathrm{U}$ of Super-ThermTaqpolymerase (JMR Holdings, London, UK) and $0.2 \mu \mathrm{M}$ of each primer(Song et al., 2007). Oligonucleotide primer sequences for hemi-nested PCR were MJN-M2235F: 5'-CATGGAAGAGTGCAACATGT-3', MJN-M2855R: 5'-TATGGTCCCTAGATGTACT-3', then MJN-M2235F and MJN-M2805R: 5'-TCTATAATAGGATCAGTCAT-3'. Initial denaturation was at $94^{\circ} \mathrm{C}$ for $5 \mathrm{~min}$, followed by 15 cycles of denaturation at $94^{\circ} \mathrm{C}$ for $40 \mathrm{sec}$, annealing at $50^{\circ} \mathrm{C}$ for $40 \mathrm{sec}$, elongation at $72^{\circ} \mathrm{C}$ for $1 \mathrm{~min}$, then 25 cycles of denaturation at $94^{\circ} \mathrm{C}$ for $40 \mathrm{sec}$, annealing at $52^{\circ} \mathrm{C}$ for $40 \mathrm{sec}$ and elongation at $72^{\circ} \mathrm{C}$ for $1 \mathrm{~min}$, in a Mastercyclerep gradient $\mathrm{S}$ (Eppendorf, Hamburg, Germany). 


\subsection{Construction of standard MJNV RNA}

MJNV RNA was constructed from pSTBlue I vector (Novagen, Darmstadt, Germany) with a cloned 570-bp fragment of the $\mathrm{M}$ segment. The plasmid was linearized with the restriction enzyme EcoR I and served as a template for RNA transcription using the MEGAscript High Yield Transcription Kit (Ambion, Austin, TX), according to the manufacturer's instructions. The synthesized RNA was incubated with DNase I (Roche Applied Science, Basel, Switzerland) at $37^{\circ} \mathrm{C}$ for $15 \mathrm{~min}$ and purified using RNA-Bee ${ }^{\mathrm{TM}}$ (Tel-Test, Inc.). RNA concentration was measured using a NanoDrop spectrophotometer. After RT-PCR using random primers $(10 \mu \mathrm{M})$, 10-fold serial dilutions of the cDNA was used to generate a real-time PCR standard curve.

\subsection{Quantitative Taqman real-time PCR}

The primers and probe targeting the MJNV M segment were designed using the Primer Express ${ }^{\circledR}$ software version 3.0 (Applied Biosystems, Foster City, CA). The M-segment primer sequences for real-timePCR were MJN-RTM2439F: 5'-

GTGAATGTAAGAAAATAACTGGAAATGACT-3' and MJN-RTM2515R: 5'GACTGTTGTGCTAAGTAGACATACCTTGA-3'. The probe (MJN-probe 2471: 5'CTCAGCACACATGGG-3') was labeled with the reporter dye FAM at the 5'-end and quencher dye MGB/non fluorescent at the 3'-end, respectively.Each $20-\mu \mathrm{L}$ reaction contained $1 \mu \mathrm{L}$ cDNA, $10 \mu \mathrm{L} 2 \mathrm{X}$ TaqMan Gene Expression master mix (Applied Biosystems), $0.5 \mu \mathrm{L}$ forward and reverse primers $(36 \mu \mathrm{M}), 0.5 \mu \mathrm{L}$ fluorescent probe $(10 \mu \mathrm{M})$, and $7.5 \mu \mathrm{L}$ double deionized water. The reaction was performed at $50^{\circ} \mathrm{C}$ for $2 \mathrm{~min}$ and $90^{\circ} \mathrm{C}$ for $10 \mathrm{~min}$, followed by 40 cycles at $95^{\circ} \mathrm{C}$ for $15 \mathrm{sec}$ and $60^{\circ} \mathrm{C}$ for $1 \mathrm{~min}$, in a StepOne Real-Time PCR system (Applied Biosystems). 


\subsection{IFA test}

Sera from infected hamsters, diluted 1:32, were placed on duplicate wells of MJNVinfectedVero E6 cells, spotted onto 10-well slides, fixed with cold acetone for 10min, and incubated at $37^{\circ} \mathrm{Cfor} 30 \mathrm{~min}$. After incubation, slides were washed and $25 \mu \mathrm{L}$ of fluorescein isothiocyanate (FITC)-labeled anti-hamsterIgG (Kirkegaard and Perry Laboratories, Gaithersburg, MD) was added to each well and incubated at $37^{\circ} \mathrm{Cfor} 30 \mathrm{~min}$. Following washes, the slides were examined for virusspecific fluorescence, using an Axioscope fluorescent microscope (Carl Zeiss AG, Oberkochen, Germany). Sera, which are screen-test positive (as defined by the intensity of intracytoplasmic granular fluorescence of ++ or +++ , were endpoint titered by testing serial two-fold dilutions.

\subsection{Histopathology and immunohistochemistry}

Lung, liver, kidney, spleen, heart and brain tissues were fixed in $10 \%$ buffered formaldehyde and embedded in paraffin.Thin sections $(4 \mu \mathrm{m})$ of each tissue, stained with hematoxylin and eosin $(\mathrm{H} \& \mathrm{E})$, were examined by light microscopy. For immunolocalization of MJNV NP, hyperimmune monoclonal mouse ascitic fluid directed against the recombinant nucleocapsid protein (rNP) of MJNV 05-11 was employed as the primary antibody and goat antimouse IgG (DAKO Cytomation, Carpinteria, CA) as the secondary antibody, according to the manufacturer's instructions. Tissue sections were initially deparaffinized in xylene and absolute ethanol, then treated with DAKO Target Retrieval Solution (DAKO Cytomation) at $90^{\circ} \mathrm{C}$ for 20min. Endogenous peroxidase activity was minimized by treating tissue sections with $3 \%$ hydrogen peroxide. The chromogen and counterstain were diaminobenzidine and hematoxylin, respectively. The slides were mounted with aqueous mounting media for viewing. 


\section{Results}

\subsection{Experimental MJNV infection}

All Syrian hamsters, aged $<1$ to 21 days(Groups I to V), developed clinical disease after intraperitoneal inoculation with 1,000 pfu of MJNV strains 04-55 and 05-11. The mortality rates in these infant and juvenile hamstersranged from 62.5-100\% (Fig. 1). Death usually occurred one to six days after the onset of clinical signs, which included weight loss, reduced activity, tachypnea, respiratory distress, hind-limb paralysis, seizures and lethargy.Surviving hamsters had profound neurological sequelae, when euthanizedat the end of the 42-day observation period.By contrast, hamsters aged 35 (Group VI) and 56 days (Groups VII)developed subclinical infection, showing no evidence of disease and no mortality following MJNV inoculation (Fig. 1). Uninoculated, control hamsters also exhibited no signs of disease.

\subsection{Anti-MJNV antibody response}

IgG antibodies against MJNV, ranging in titer from 512 to 4,096 by the IFA test, were found in sera from hamsters in Groups I to V with clinical disease (Table 1). High-titers of IgG antibodies were detectable at the time of death between 8 to 16 days post-inoculation. Terminal sera from surviving hamsters in Groups I to V, collected at 42 days post-inoculation, had similarly high titers of anti-MJNV IgG antibodies. Although without clinical disease, hamsters in Group VI (35 days old) and Group VII (56 days old) exhibited anti-MJNV antibodies by the IFA test, at the end of the 42-day observation period (Table 1).

\subsection{Conventional RT-PCR}


Using conventional RT-PCR, MJNV RNA was detected in heart, lung, kidney, spleenand brain from all or nearly all experimentally infected hamsters in each group less than 14 days of age (Groups I to IV) (Table 2). MJNV strain 04-55 was more hepatotropic than MJNV strain 0511. In Group V (21 days of age), moribund and surviving hamsters at 42 days post-inoculation also had widespread distribution of MJNV RNA, particularly in lung and brain. Similarly, in hamsters inoculated at 35 days of age (Groups VI), MJNV RNA was absent in visceral organs, but was regularly detectable in brain. Interestingly, MJNV RNA was even found in brains of two hamsters inoculated with either MJNV strain 04-55 or 05-11 at 56 days of age, despite showing no clinical signs of disease, suggesting that MJNV may be neurotropic in hamsters.

\subsection{Quantitative real-time PCR}

As determined by quantitative real-time PCR, viral RNA copies in the brain of MJNVinfected hamsters usually exceeded that in other organs(Fig. 2). This was particularly true for hamsters in Groups III, IV and V, inoculated at 10, 14 and 21 days of age, in which MJNV RNA copies in brain were 50 to 1,000 times higher than in heart, lung, liver, kidney, spleen and small intestine. In hamsters infected with MJNV strain 04-55, viral RNA load decreased in an agedependent fashion in the heart, lung, spleen and small intestine but not in the liver, kidney and brain (Fig. 2A). A less clear organ-specific pattern was found for hamsters infected with MJNV strain 05-11, butin general an age-dependent decrease in MJNVRNA load was also evident,except in brain, whichexhibited $10^{4}$ to $10^{5} \mathrm{MJNV}$ RNAcopies/g(Fig. 2B).Moreover,Syrian hamsters inoculated at 35 and 56 days of age exhibited MJNV RNA in brain at 42 days following inoculation, despite showing no neurological signs (Table 2 and Fig. 2). 


\subsection{Histopathology}

Light-microscopic examination of H\&E-stained tissues from hamsters succumbing to experimental infection with MJNV strains 04-55 and 05-11 revealed widespread abnormalities in the lung, liver and brain (Fig. 3 and 4). In particular, alveolar hemorrhage, severe vascular congestion, interstitial thickening and severe pneumonia were observed in lung tissues of hamstersinfected with MJNV 04-55 (Fig. 3A to 3E) andMJNV 05-11 (Fig. 3F and 3G). Liver tissues exhibited portal tract and hepatic inflammation (Fig. 4A and 4B), as well as acute inflammation with necrosis of hepatocytes(Fig. 4C). Severe inflammation of the meninges and pons (Fig. 4E and 4F) and acute inflammation of the brain parenchyma with vascular proliferation (Fig. 4G) were also observed in MJNV-infected hamsters. No significant pathologic changes were found inkidney, spleen and intestine (data not shown).

\subsection{Immunohistochemistry}

By immunostaining, MJNV NP antigen was detected in the alveoli andinterstitium of lung tissues from hamsters infected with MJNV 04-55 and MJNV 05-11(Fig. 5A and 5B). Viral antigens were also detected in the cytoplasm of glial cells in brain tissue from MJNV 04-55 infected hamsters (Fig. 5D). Interestingly, viral antigens were widely distributed in cortical neurons, including dendrites without inflammatory cell infiltrations, in some areas of the meninges and in Purkinje cells and granular layers of the cerebellum. MJNV NP antigen was not detected in other tissues (data not shown).

\section{Discussion}


Developing animal models of hantavirus infectionis vital to gain a better understanding about hantavirus persistence. Such models have used the natural reservoir host species, such as wild-caught striped field mice (Apodemusagrarius) for HTNV(Lee et al., 1981), laboratory-bred bank voles (Myodesglareolus) for PUUV(Yanagihara et al., 1985a), and free-ranging deer mice (Peromyscusmaniculatus) for SNV(Botten et al., 2000, 2003). More readily available small laboratory rodent species have also been employed to study hantavirus persistence, such as brown rats (Rattusnorvegicus) for SEOV infection(Easterbrook et al., 2007), and Syrian hamsters and Mongolian gerbils (Merionesunguiculatus) for PUUV infection(Sanada et al., 2011; Yanagihara et al., 1985b).

Animal models for hantavirus infection and disease would also facilitate the testing of candidate vaccines and new therapies.Attempts at developing models of HFRS and HPS in nonhuman primates have had mixed results(Groen et al., 1995; Klingström et al., 2002; McElroy et al., 2002; Sironen et al., 2008; Yanagihara et al., 1988). For example, following intratracheal inoculation with PUUV, cynomolgus monkeys (Macacafascicularis) exhibited mild proteinuria and/or microhematuria(Groen et al., 1995; Klingström et al., 2002). Detection of PUUV RNA by in situ hybridization and localization of PUUV NP by immunohistochemistry in kidney, spleen and liver tissues, as well as elevated cytokine levels, are consistent with those observed in patients with HFRS(Klingström et al., 2002; Sironen et al., 2008). At the same time, mild, transient proteinuria and azotemia were produced in cynomolgus monkeys and a chimpanzee (Pan troglodytes) following intravenous inoculation with Prospect Hill virus, a putative nonpathogenic hantavirus harbored by meadow voles(Yanagihara et al., 1988). By contrast, cynomolgus macaques inoculated by the intravenous or aerosol route with the highly lethal HPScausing ANDV did not develop clinical disease(McElroy et al., 2002). 
Attempts to replicate HFRS in rodents have been largely unsuccessful. Generally, experimental hantavirus infection in rodents are either asymptomatic (Wahl-Jensen et al., 2007; Yanagihara et al., 1985b) or characterized by differential age-dependent susceptibility and fatal meningoencephalitis(Kim and McKee, 1985; Kurata et al., 1983; McKee et al., 1985; Nakamura et al., 1985; Wichmann et al., 2002; Yamanouchi et al., 1984; Yoshimatsu et al., 1997). Recently, the age-dependent susceptibility of mice to lethal hantavirusmeningoencephalitis has been attributed to the mouse strain. That is, while adult mice are usually resistant, several strains of adult Musmusculus (C57BL/6, BALB/c, AKR/J, and SJL/J) develop fatal neuroinvasive disease following intraperitoneal inoculation with HTNV(Wichmann et al., 2002). Although experimental meningoencephalitis in mice does not provide a suitable HFRS disease model, it has nevertheless served as an acceptable infection model in which to test the efficacy of the antiviral drug, ribavirin(Huggins et al., 1986). Also, a PUUV infection model in bank voles has been used to test a chimeric HBV core-PUUV NP vaccine(Ulrich et al., 1998) and protection against SEOV infection was achieved in Syrian hamsters using a DNA vaccine construct containing the SEOV M segment(Hooper et al., 1999).

A major breakthrough in hantavirology has been the development of a lethal HPS model in Syrian hamsters inoculated with ANDV (Hooper et al., 2001). Experimental ANDV infection in adult Syrian hamsters is characterized by acute respiratory failure and histopathological findings in the lung that are essentially indistinguishable from that in HPS in humans(Hooper et al., 2001; Safronetz et al., 2011). However, not all HPS-causing hantaviruses uniformly produce HPS-like diseases in Syrian hamsters. For example, SNV and CHOV, two hantaviruses known to cause HPS in North and South America, produce subclinical infection in hamsters(Eyzaguirre et al., 2008; Wahl-Jensen et al., 2007). Recently, transient immunosuppression with dexamethasone 
and cyclophosphamide monohydrate has rendered hamsters susceptible to HPS with SNV (Brocato et al., 2014).

In this exploratory study, we attempted to ascertain the pathogenic potential of a newly isolated shrew-borne hantavirusby inoculating Syrian hamsters of different ages. Despite differences in experimental design from previous studies, including age, route of inoculation and inoculum dose, MJNV-infected Syrian hamsters shared clinical andpathological features reported in hamsters experimentally infected with ANDV and SNV(Brocato et al., 2014; Hooper et al., 2001).Similarities included respiratory distress, clinical time course, presence of virus-specific IgG at the onset of clinical disease, widespread inflammation in lung and liver, distribution of hantaviral antigen in microvascular endothelial cells, and overall high mortality. However, distinct differences were also evident. MJNV-infected infant and juvenilehamsters developed neurologic disease, characterized by paralysis and seizures, whereas these features are absent in ANDV- and SNV-infected adult hamsters. Also, MJNV caused hepatic necrosis, whereas ANDV and SNV do not. Also, in stark contrast to experimental ANDV and SNV infection in hamsters, pulmonary edema was not evident in MJNV-infected hamsters. This is reminiscent of what has been reported for $\mathrm{CHOV}$, an HPS-causing hantavirus. That is, despite the widespread distribution of viral antigen in pulmonary microvascular endothelial cells, HPSlike disease and pulmonary edema were not observed in CHOV-infected Syrian hamsters (Eyzaguirre et al., 2008).

Importantly, experimental MJNV infection in infant and juvenile hamsters exhibited an age-dependent susceptibility to lethal disease, not unlike the meningoencephalitis described previously in mice and rats experimentally infected with HTNV(Kurata et al., 1983; McKee et al., 1985; Nakamura et al., 1985; Yamanouchi et al., 1984). That is, MJNV caused disease only 
in hamsters aged three weeks or younger, and not in hamsters inoculated at 35 and 56 days of age. On the other hand, ANDV and SNV cause lethal HPS-like disease in adult hamsters.

The development of animal models of human diseases, or the use of animals to predict human diseases, is fraught with uncertainties about relevance. For example, Maporal virus, which causes an HPS-like disease in hamsters(Milazzo et al., 2002), is not associated with HPS in humans, and conversely, CHOV, which causes HPS in humans (Nelson et al., 2010), does not cause HPS in hamsters (Eyzaguirre et al., 2008). Thus, despite the MJNV-associated pathology in hamsters, this does not prove that MJNV is pathogenic in humans. Nevertheless,the findings reported here suggest that hamsters provide an acute MJNV disease model, and may be a convenient experimental host for ascertaining the infectivity and pathogenicity of newfound nonrodent-borne hantaviruses, as well as provide helpful clues about the type(s) of disease MJNV might cause in humans. That is, while neurological manifestations have only rarely been a feature of rodent-borne hantavirus infection in humans (Cerar et al., 2007; Chan et al., 1996), theneurotropismand neuropathology, with high viral load in brains ofMJNV-infected hamsters, warrant targeted investigations for disease correlates in humans. 


\section{Acknowledgments}

This work was supported in part by grants from the National Institute of Allergy and Infectious Diseases (R01AI075057)and the National Institute of General Medical Sciences (P20GM103516) of the National Institutes of Health, and the Global Emerging Infections Surveillance and Response System (GEIS), U.S. Department of Defense. 


\section{References}

Bennett, S.N., Gu, S.H., Kang, H.J., Arai, S., Yanagihara, R., 2014. Reconstructing the evolutionary origins and phylogeography of hantaviruses. Trends Microbiol. 22, 473-482.

Botten, J., Mirowsky, K., Kusewitt, D., Bharadwaj, M., Yee, J., Ricci, R., Feddersen, R.M., Hjelle, B.,2000. Experimental infection model for Sin Nombre hantavirus in the deer mouse (Peromyscus maniculatus). Proc. Natl. Acad. Sci. U. S. A. 97, 10578-10583.

Botten, J., Mirowsky, K., Kusewitt, D., Ye, C.Y., Gottlieb, K., Prescott, J., Hjelle, B.,2003. Persistent Sin Nombre virus infection in the deer mouse (Peromyscus maniculatus) model: sites of replication and strand-specific expression. J. Virol. 77, 1540-1550.

Brocato, R.L., Hammerbeck, C.D., Bell, T.M., Wells, J.B., Queen, L.A., Hooper, J.W., 2014. A lethal disease model for hantavirus pulmonary syndrome in immunosuppressed Syrian hamsters infected with Sin Nombre virus. J. Virol. 88, 811-819.

Brummer-Korvenkontio, M., Vaheri, A., Hovi, T., von Bonsdorff, C.H., Vuorimies, J., Manni, T., Penttinen, K., Oker-Blom, N., Lähdevirta, J., 1980. Nephropathia epidemica: detection of antigen in bank voles and serologic diagnosis of human infection. J. Infect. Dis.141, 131134.

Carey, D.E., Reuben, R., Panicker, K.N., Shope, R.E., Myers, R.M.,1971. Thottapalayam virus: a presumptive arbovirus isolated from a shrew in India. Indian J. Med. Res. 59, 1758-1760.

Cerar, D., Avsic-Zupanc, T., Jereb, M., Strle, F.,2007.Severe neurological manifestation of Dobrava hantavirus infection. J. Med. Virol. 79, 1841-1843.

Chan, K.P., Chan, Y.C., Doraisingham, S.,1996. A severe case of hemorrhagic fever with renal syndrome in Singapore. Southeast Asian J. Trop. Med. Public Health 27, 408-410. 
Chu, Y.K., Jennings, G.B., Schmaljohn, C.S., 1995. A vaccinia virus-vectored Hantaan virus vaccine protects hamsters from challenge with Hantaan and Seoul viruses but not Puumala virus. J. Virol. 69, 6417-6423.

Duchin, J.S., Koster, F.T., Peters, C.J., Simpson, G.L., Tempest, B., Zaki, S.R., Ksiazek, T.G., Rollin, P.E., Nichol, S., Umland, E.T., Moolenaar, R.L., Reef, S.E., Nolte, K.B., Gallaher, M.M., Butler, J.C., Breiman, R.F., for the Hantavirus Study Group, 1994. Hantavirus pulmonary syndrome - a clinical description of 17 patients with a newly recognized disease. N. Engl. J. Med. 330, 949-955.

Easterbrook, J.D., Zink, M.C., Klein, S.L.,2007. Regulatory T cells enhance persistence of the zoonotic pathogen Seoul virus in its reservoir host. Proc. Natl. Acad. Sci. U. S. A. 104, $15502-15507$.

Eyzaguirre, E.J., Milazzo, M.L., Koster, F.T., Fulhorst, C.F.,2008. Choclo virus infection in the Syrian golden hamster. Am. J. Trop. Med. Hyg. 78, 669-674.

Groen, J., Gerding, M., Koeman, J.P., Roholl, P.J.M., Vanamerongen, G., Jordans, H.G.M., Niesters, H.G.M., Osterhaus, A.D.M.E.,1995. A macaque model for hantavirus infection. J. Infect. Dis. 172, 38-44.

Hooper, J.W., Kamrud, K.I., Elgh, F., Custer, D., Schmaljohn, C.S.,1999. DNA vaccination with hantavirus M segment elicits neutralizing antibodies and protects against Seoul virus infection. Virology 255, 269-278.

Hooper, J.W., Larsen, T., Custer, D.M., Schmaljohn, C.S.,2001. A lethal disease model for hantavirus pulmonary syndrome. Virology 289, 6-14.

Hooper, J.W., Josleyn, M., Ballantyne, J., Brocato, R., 2013. A novel Sin Nombre virus DNA vaccine and its inclusion in a candidate pan-hantavirus vaccine against hantavirus 
pulmonary syndrome (HPS) and hemorrhagic fever with renal syndrome (HFRS).

Vaccine. 31, 4314-4321.

Huggins, J.W., Kim, G.R., Brand, O.M.,McKee, K.T.,1986. Ribavirin therapy for Hantaan virus infection in suckling mice. J. Infect. Dis. 153, 489-497.

Kim, G.R., McKee, K.T., Jr.,1985. Pathogenesis of Hantaan virus infection in suckling mice: clinical, virologic, and serologic observations. Am. J. Trop. Med. Hyg. 34, 388-395.

Klingström, J., Plyusnin, A., Vaheri, A., Lundkvist, A.,2002. Wild-type Puumala hantavirus infection induces cytokines, C-reactive protein, creatinine, and nitric oxide in cynomolgus macaques. J. Virol. 76, 444-449.

Kurata, T., Tsai, T.F., Bauer, S.P., McCormick, J.B.,1983. Immunofluorescence studies of disseminated Hantaan virus infection of suckling mice. Infect. Immun. 41, 391-398.

Lee, H.W., French, G.R., Lee, P.W., Baek, L.J., Tsuchiya, K., Foulke, R.S., 1981. Observations on natural and laboratory infection of rodents with the etiologic agent of Korean hemorrhagic fever. Am. J. Trop. Med. Hyg. 30, 477-482.

Lee, H.W., Lee, P.W., Johnson, K.M.,1978. Isolation of the etiologic agent of Korean hemorrhagic fever. J. Infect. Dis. 137, 298-308.

Lee, H.W., Vandergroen, G.,1989. Hemorrhagic fever with renal syndrome. Prog. Med. Virol. 36, 62-102.

Lopez, N., Padula, P., Rossi, C., Lazaro, M.E., FranzeFernandez, M.T.,1996. Genetic identification of a new hantavirus causing severe pulmonary syndrome in Argentina. Virology 220, 223-226.

McElroy, A.K., Bray, M., Reed, D.S., Schmaljohn, C.S.,2002. Andes virus infection of cynomolgus macaques. J. Infect. Dis. 186, 1706-1712. 
McKee, K.T., Kim, G.R., Green, D.E., Peters, C.J.,1985. Hantaan virus infection in suckling mice - virologic and pathologic correlates. J. Med. Virol. 17, 107-117.

Milazzo, M.L., Eyzaguirre, E.J., Molina, C.P., Fulhorst, C.F.,2002. Maporal viral infection in the Syrian golden hamster: a model of hantavirus pulmonary syndrome. J. Infect. Dis. 186, $1390-1395$.

Nakamura, T., Yanagihara, R., Gibbs, C.J., Jr., Amyx, H.L., Gajdusek, D.C., 1985.

Differentialsusceptibility and resistance of immunocompetent and immunodeficient mice to fatal Hantaan virus infection. Arch. Virol. 86, 109-120.

Nelson, R., Canate, R., Pascale, J.M., Dragoo, J.W., Armien, B., Armien, A.G., Koster, F.,2010. Confirmation of Choclo virus as the cause of hantavirus cardiopulmonary syndrome and high serum antibody prevalence in Panama. J. Med. Virol. 82, 1586-1593.

Nichol, S.T., Spiropoulou, C.F., Morzunov, S., Rollin, P.E., Ksiazek, T.G., Feldmann, H., Sanchez, A., Childs, J., Zaki, S., Peters, C.J.,1993. Genetic identification of a hantavirus associated with an outbreak of acute respiratory illness. Science 262, 914-917.

Ravkov, E.V., Rollin, P.E., Ksiazek, T.G., Peters, C.J., Nichol, S.T.,1995. Genetic and serologic analysis of Black Creek Canal virus and its association with human disease and Sigmodon hispidus infection. Virology 210, 482-489.

Safronetz, D., Zivcec, M., Lacasse, R., Feldmann, F., Rosenke, R., Long, D., Haddock, E., Brining, D., Gardner, D., Feldmann, H., Ebihara, H.,2011. Pathogenesis and host response in Syrian hamsters following intranasal infection with Andes virus. PLoS Pathog. 7, e1002426.

Safronetz, D., Ebihara, H., Feldmann, H., Hooper, J.W., 2012. The Syrian hamster model of hantavirus pulmonary syndrome. Antiviral Res. 95, 282-292. 
Sanada, T., Kariwa, H., Nagata, N., Tanikawa, Y., Seto, T., Yoshimatsu, K., Arikawa, J., Yoshii, K., Takashima, I.,2011. Puumala virus infection in Syrian hamsters (Mesocricetus auratus) resembling hantavirus infection in natural rodent hosts. Virus Res. 160, 108-119.

Schmaljohn, C.S., Dalrymple, J.M.,1983. Analysis of Hantaan virus RNA: evidence for a new genus of Bunyaviridae. Virology 131, 482-491.

Schmaljohn, C.S., Hasty, S.E., Harrison, S.A., Dalrymple, J.M.,1983. Characterization of Hantaan virions, the prototype virus of hemorrhagic fever with renal syndrome. J. Infect. Dis. $148,1005-1012$.

Schmaljohn, C.S., Chu, Y.-K., Schmaljohn, A.L., Dalrymple, J.M., 1990. Antigenic subunits of Hantaan virus expressed by baculovirus and vaccinia virus recombinants. J. Virol. 64, 3162-3170.

Sironen, T., Klingström, J., Vaheri, A., Andersson, L.C., Lundkvist, A., Plyusnin, A.,2008. Pathology of Puumala hantavirus infection in macaques. PLoS One 3, e3035.

Song, J.W., Baek, L.J., Schmaljohn, C.S., Yanagihara, R.,2007. Thottapalayam virus, a prototype shrewborne hantavirus. Emerg. Infect. Dis. 13, 980-985.

Song, J.W., Kang, H.J., Gu, S.H., Moon, S.S., Bennett, S.N., Song, K.J., Baek, L.J., Kim, H.C., O'Guinn, M.L., Chong, S.T., Klein, T.A., Yanagihara, R.,2009. Characterization of Imjin virus, a newly isolated hantavirus from the Ussuri white-toothed shrew (Crocidura lasiura). J. Virol. 83, 6184-6191.

Ulrich, R., Lundkvist, A., Meisel, H., Koletzki, D., Sjolander, K.B., Gelderblom, H.R., Borisova, G., Schnitzler, P., Darai, G., Krüger, D.H.,1998. Chimaeric HBV core particles carrying a defined segment of Puumala hantavirus nucleocapsid protein evoke protective immunity in an animal model. Vaccine 16, 272-280. 
Wahl-Jensen, V., Chapman, J., Asher, L., Fisher, R., Zimmerman, M., Larsen, T.,Hooper, J.W., 2007. Temporal analysis of Andes virus and Sin Nombre virus infections of Syrian hamsters. J. Virol. 81, 7449-7462.

Wichmann, D., Grone, H.J., Frese, M., Pavlovic, J., Anheier, B., Haller, O., Klenk, H.D., Feldmann, H.,2002. Hantaan virus infection causes an acute neurological disease that is fatal in adult laboratory mice. J. Virol. 76, 8890-8899.

Yamanouchi, T., Domae, K., Tanishita, O., Takahashi, Y., Yamanishi, K., Takahashi, M., Kurata, T.,1984. Experimental infection in newborn mice and rats by hemorrhagic fever with renal syndrome (HFRS) virus. Microbiol. Immunol. 28, 1345-1353.

Yanagihara, R., Amyx, H.L., Gajdusek, D.C.,1985a. Experimental infection with Puumala virus, the etiologic agent of nephropathia epidemica, in bank voles (Clethrionomysglareolus). J. Virol. 55, 34-38.

Yanagihara, R., Amyx, H.L., Lee, P.W., Asher, D.M., Gibbs, C.J., Jr., Gajdusek, D.C.,1988. Experimental hantavirus infection in nonhuman primates. Arch. Virol. 101, 125-130.

Yanagihara, R., Gu, S.H., Arai, S., Kang, H.J., Song, J.-W.,2014. Hantaviruses: rediscovery and new beginnings. Virus Res. 187, 6-14.

Yanagihara, R., Gajdusek., D.C.,1988. Hemorrhagic fever with renal syndrome: a historical perspective and review of recent advances. In:Gear, J.H.S, CRC handbook of viral and rickettsial hemorrhagic fevers. CRC press, Inc., Boca Raton, FL., 151-188.

Yanagihara, R., Goldgaber, D., Gajdusek, D.C.,1985b. Propagation of nephropathia epidemica virus in Mongolian gerbils. J. Virol. 53, 973-975.

Yoshimatsu, K., Arikawa, J., Ohbora, S.,Itakura, C., 1997. Hantavirus infection in SCID mice. J. Vet. Med. Sci. 59, 863-868. 
Zaki, S.R., Greer, P.W., Coffield, L.M., Goldsmith, C.S., Nolte, K.B., Foucar, K., Feddersen, R.M., Zumwalt, R.E., Miller, G.L., Khan, A.S., Rollin, P.E., Ksiazek, T.G., Nichol, S.T., Mahy, B.W.J., Peters, C.J.,1995. Hantavirus pulmonary syndrome - Pathogenesis of an emerging infectious disease. Am. J. Pathol. 146, 552-579. 
Table 1. Serum anti-MJNV IgG antibodies by IFA in hamsters experimentally infected with MJNV strains 04-55 and 05-11.

\section{MJNV strain 04-55}

\begin{tabular}{|c|c|c|c|c|c|c|c|c|c|}
\hline Age Group & No. & $\begin{array}{l}\text { Clinical } \\
\text { Outcome }\end{array}$ & $\begin{array}{c}\text { Days } \\
\text { Post-inoculation }\end{array}$ & $\begin{array}{c}\text { IFA } \\
\text { Titer }\end{array}$ & Age Group & No. & $\begin{array}{l}\text { Clinical } \\
\text { Outcome }\end{array}$ & $\begin{array}{c}\text { Days } \\
\text { Post-inoculation }\end{array}$ & $\begin{array}{l}\text { IFA } \\
\text { Titer }\end{array}$ \\
\hline \multirow[t]{9}{*}{ I (<1 day) } & 1 & $\mathrm{sd}$ & 13 & 512 & I (<1 day) & 1 & sd & 10 & 4,096 \\
\hline & 2 & $\mathrm{sd}$ & 13 & 512 & & 2 & sd & 10 & 4,096 \\
\hline & 3 & $\mathrm{sd}$ & 14 & 2,048 & & 3 & sd & 10 & 2,048 \\
\hline & 4 & $\mathrm{sd}$ & 14 & 4,096 & & 4 & sd & 11 & 4,096 \\
\hline & 5 & SS & 42 & 4,096 & & 5 & sd & 11 & 4,096 \\
\hline & & & & & & 6 & sd & 11 & 4,096 \\
\hline & & & & & & 7 & sd & 11 & 4,096 \\
\hline & & & & & & 8 & sd & 12 & 4,096 \\
\hline & & & & & & 9 & sd & 13 & 4,096 \\
\hline \multirow[t]{8}{*}{ II (5 days) } & 1 & sd & 10 & 4,096 & II (5 days) & 1 & sd & 10 & 4,096 \\
\hline & 2 & sd & 10 & 2,048 & & 2 & sd & 10 & 2,048 \\
\hline & 3 & $\mathrm{sd}$ & 10 & 512 & & 3 & sd & 10 & 2,048 \\
\hline & 4 & sd & 10 & 1,024 & & 4 & sd & 12 & 4,096 \\
\hline & 5 & $\mathrm{sd}$ & 10 & 4,096 & & 5 & Ss & 42 & 2,048 \\
\hline & 6 & sd & 12 & 1,024 & & 6 & SS & 42 & 2,048 \\
\hline & 7 & sd & 12 & 512 & & & & & \\
\hline & 8 & sd & 12 & 512 & & & & & \\
\hline \multirow[t]{8}{*}{ III (10 days) } & 1 & sd & 9 & 512 & III (10 days) & 1 & sd & 8 & 4,096 \\
\hline & 2 & $\mathrm{sd}$ & 9 & 1,024 & & 2 & sd & 10 & 4,096 \\
\hline & 3 & sd & 9 & 4,096 & & 3 & sd & 10 & 4,096 \\
\hline & 4 & $\mathrm{sd}$ & 9 & 2,048 & & 4 & sd & 15 & 4,096 \\
\hline & 5 & $\mathrm{sd}$ & 9 & 4,096 & & 5 & sd & 16 & 2,048 \\
\hline & 6 & sd & 10 & 4,096 & & 6 & ss & 42 & 2,048 \\
\hline & 7 & $\mathrm{sd}$ & 11 & 4,096 & & 7 & SS & 42 & 2,048 \\
\hline & & & & & & 8 & SS & 42 & 2,048 \\
\hline \multirow[t]{2}{*}{ IV (14 days) } & 1 & sd & 9 & 4,096 & IV (14 days) & 1 & sd & 10 & 4,096 \\
\hline & 2 & $\mathrm{sd}$ & 11 & 4,096 & & 2 & sd & 10 & 4,096 \\
\hline
\end{tabular}

\section{MJNV strain 05-11}


Gu et al.

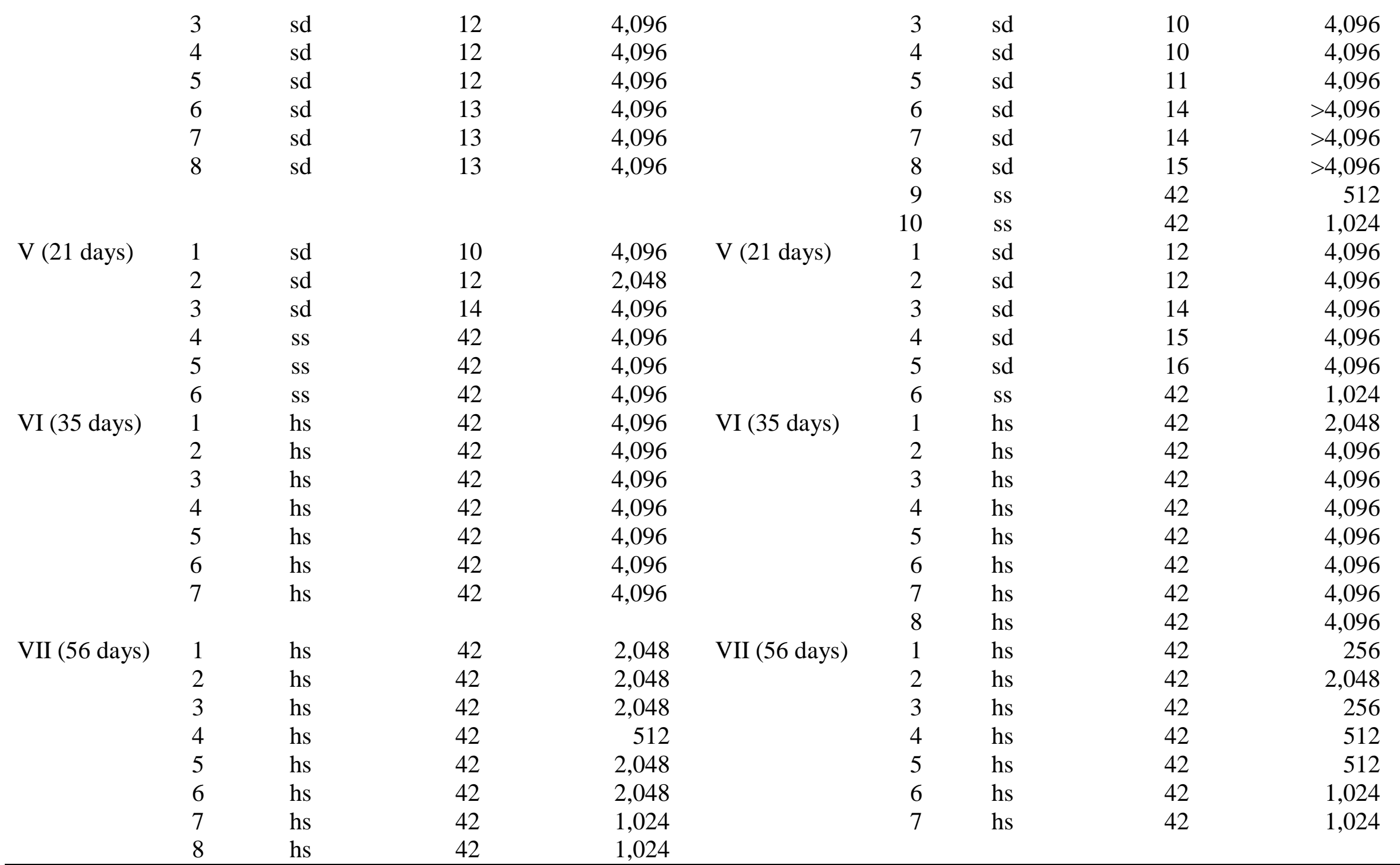

Abbreviations for clinical outcomes: sd, sick and dead; ss, sick but surviving at 42 days post-inoculation; hs, healthy and surviving at 42 days post-inoculation

Uninoculated control hamsters in each age group, numbering between 5 and 10, remained healthy during the 42-day study period. 
Table2. Viral RNA in tissues of hamsters inoculated intraperitoneally with MJNV strains 04-55 and 05-11, as detected by conventional RT-PCR.

\begin{tabular}{|c|c|c|c|c|c|c|c|c|}
\hline \multirow{2}{*}{\multicolumn{2}{|c|}{ Age Group }} & \multicolumn{7}{|c|}{ Tissues (No. viral RNA/no. tested) } \\
\hline & & Heart & Lung & Liver & Kidney & Spleen & Intestine & Brain \\
\hline \multicolumn{9}{|c|}{$\underline{\text { MJNV 04-55 }}$} \\
\hline I & ( $<1$ day) & $4 / 5$ & $4 / 5$ & $4 / 5$ & $4 / 5$ & $4 / 5$ & $4 / 5$ & $5 / 5$ \\
\hline II & (5 days) & $8 / 8$ & $8 / 8$ & $8 / 8$ & $8 / 8$ & $8 / 8$ & $8 / 8$ & $8 / 8$ \\
\hline III & (10 days) & $7 / 7$ & $7 / 7$ & $7 / 7$ & $7 / 7$ & $7 / 7$ & $7 / 7$ & $7 / 7$ \\
\hline IV & (14 days) & $8 / 8$ & $8 / 8$ & $8 / 8$ & $8 / 8$ & $8 / 8$ & $5 / 8$ & $8 / 8$ \\
\hline V & (21 days) & $3 / 6$ & $4 / 6$ & $3 / 6$ & $3 / 6$ & $3 / 6$ & $2 / 6$ & $6 / 6$ \\
\hline VI & (35 days) & $2 / 7$ & $0 / 7$ & $0 / 7$ & $0 / 7$ & $0 / 7$ & $0 / 7$ & $6 / 7$ \\
\hline VII & (56 days) & $0 / 8$ & $0 / 8$ & $0 / 8$ & $0 / 8$ & $0 / 8$ & $0 / 8$ & $2 / 8$ \\
\hline $\mathrm{Neg}$ & tive control $*$ & $0 / 5$ & $0 / 5$ & $0 / 5$ & $0 / 5$ & $0 / 5$ & $0 / 5$ & $0 / 5$ \\
\hline \multicolumn{9}{|c|}{ MJNV 05-11 } \\
\hline I & (<1 day) & $9 / 9$ & $9 / 9$ & $8 / 9$ & $9 / 9$ & $9 / 9$ & $9 / 9$ & $9 / 9$ \\
\hline II & (5 days) & $5 / 6$ & $5 / 6$ & $1 / 6$ & $5 / 6$ & $5 / 6$ & $5 / 6$ & $6 / 6$ \\
\hline III & (10 days) & $7 / 8$ & $8 / 8$ & $0 / 8$ & $8 / 8$ & $8 / 8$ & $5 / 8$ & $8 / 8$ \\
\hline IV & (14 days) & $9 / 10$ & $10 / 10$ & $2 / 10$ & $10 / 10$ & $7 / 10$ & $0 / 10$ & $10 / 10$ \\
\hline V & (21days) & $6 / 6$ & $5 / 6$ & $0 / 6$ & $6 / 6$ & $3 / 6$ & $1 / 6$ & $6 / 6$ \\
\hline VI & (35 days) & $0 / 8$ & $0 / 8$ & $0 / 8$ & $0 / 8$ & $0 / 8$ & $0 / 8$ & $7 / 8$ \\
\hline VII & (A56 days) & $0 / 7$ & $1 / 7$ & $0 / 7$ & $0 / 7$ & $0 / 7$ & $0 / 7$ & $2 / 7$ \\
\hline \multicolumn{2}{|c|}{ Negative control* } & $0 / 5$ & $0 / 5$ & $0 / 5$ & $0 / 5$ & $0 / 5$ & $0 / 5$ & $0 / 5$ \\
\hline
\end{tabular}

* Negative controls were not inoculated. 
MEEGID 15-00487R1

Gu et al.

\section{Figure Legends}

Fig. 1. Survival rates of Syrian hamsters inoculated at different ages with 1,000 pfu of MJNV strains 04-55 (A) and 05-11 (B).NC denotes negative control.

Fig. 2. Real-time RT-PCR quantification of viral RNA in heart, lung, liver, kidney, spleen and brain of Syrian hamsters inoculated with MJNV strains 04-55 (A) and 05-11 (B).MJNV RNA copies per gram of tissues from individual hamsters are shown for each age group. Terminal tissues from surviving hamsters were collected at 42 days following inoculation. MJNV RNA copies in small intestine were similar to that in other tissues (data not shown).

Fig. 3. Histopathology of lung tissues obtained from moribund hamsters infected with MJNV. (A) alveolar hemorrhage in MJNV 04-55 infected hamster, group I (Age<24hr), No. 2; (B) interstitial pneumonia in MJNV 04-55 infected hamster, group I (Age<24hr), No. 5; (C) severe congestion in MJNV 04-55 infected hamster, group III (Age 10 days), No. 4; (D) interstitial pneumonia and congestion in MJNV 04-55 infected hamster, group IV (Age 14 days), No. 8; (E) interstitial thickening in MJNV 04-55 infected hamster, group VII (Age 56 days), No. 6; (F) alveolar old hemorrhage and congestion in MJNV 05-11 infected hamster, group III (Age 10 days), No. 2; (G) interstitial pneumonia, severe alveolar hemorrhage and congestion in MJNV 05-11 infected hamster, group V (Age 21 days), No. 2; (H) lung from control uninfected hamster. H\&E stain;Original magnifications, X200. 
MEEGID 15-00487R1

Fig. 4. Histopathology of liver and brain tissues obtained from hamsters infected with MJNV. (A) portal inflammation in liver of MJNV-infected hamster, group I (Age<24hr), No. 5; (B) portal inflammation and hepatic perivenulitis in liver of MJNV 04-55 infected hamster, group IV (Age 14 days), No. 8; (C) acute inflammation with necroses of hepatocytes in liver of MJNV 05-11 infected hamster, group IV (Age 14 days), No. 10; (D) liver from control uninfected hamster. (E) inflammation in brain of MJNV 04-55 infected hamster, group I (<24hr), No. 5; (F) inflammation in brain of MJNV 04-55 infected hamster, group III (Age 10 days), No. 5; (G) acute inflammation in brain of MJNV 04-55 infected hamster, group IV, No. 8; $(\mathrm{H})$ brain from control uninfected hamster.H\&E stain;Original magnifications, X200.

Fig. 5.Immunohistochemical localization of MJNV NP in lung and brain tissue of hamsters inoculated with MJNV. (A) MJNV 04-55 infected hamster group IV (Age 14 days), No. 8. (B) MJNV 05-11 infected hamster group V (Age 21 days), No. 2. (C) lung from control uninfected hamster.(D) MJNV 04-55 infected hamster group IV (Age 14 days), No. 8. (E) brain from control uninfected hamster. Original magnifications, X400. 

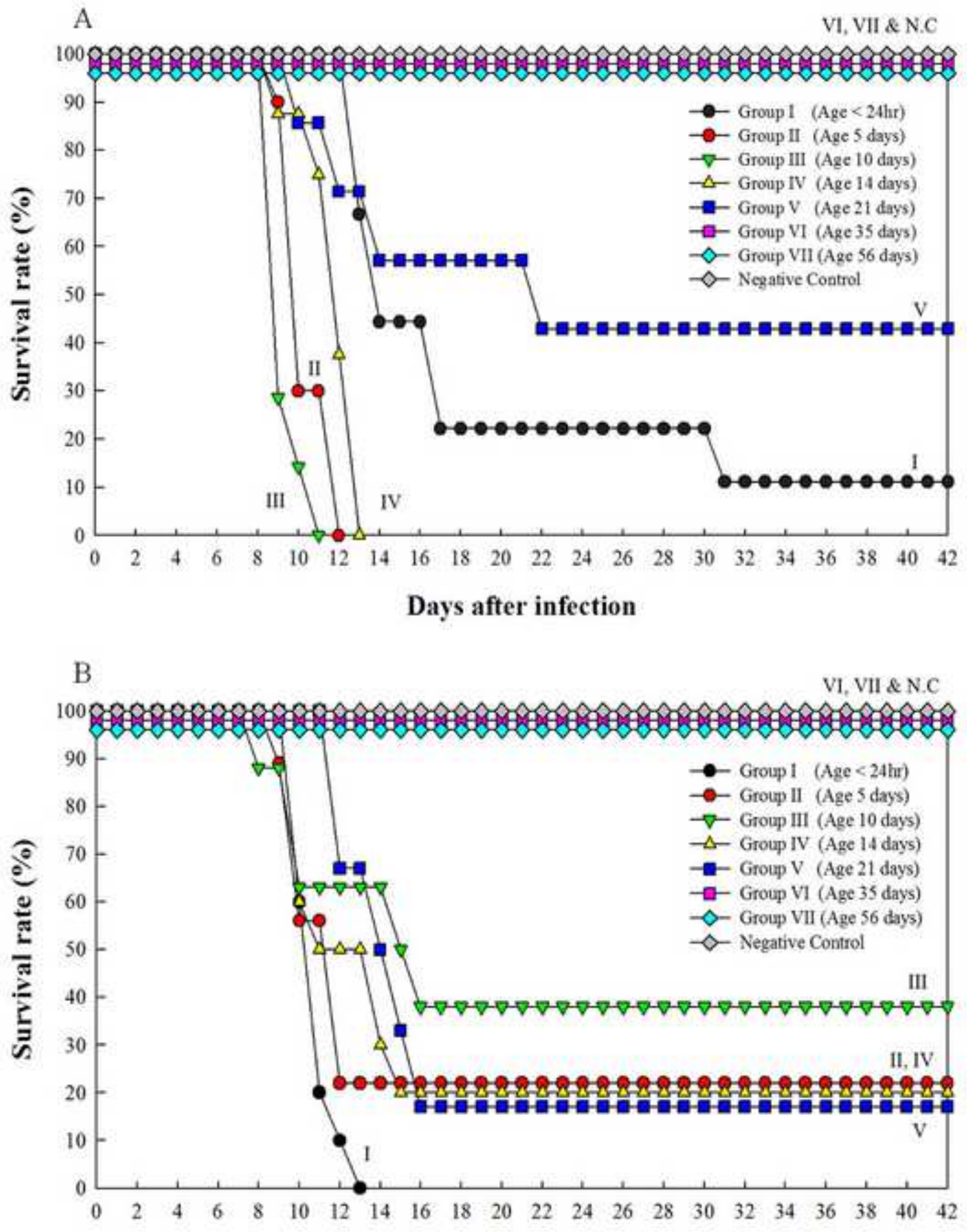

Days after infection 
A
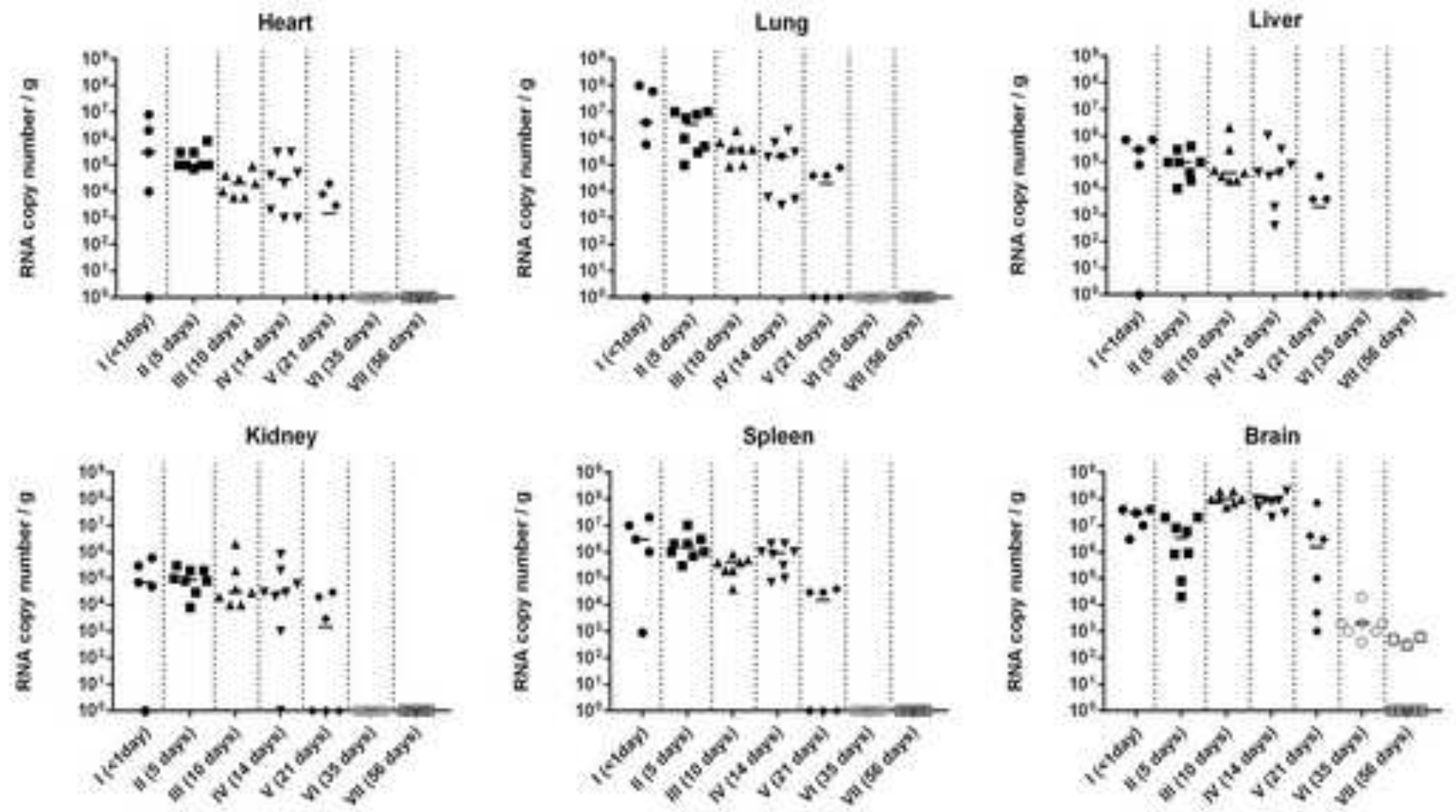

B
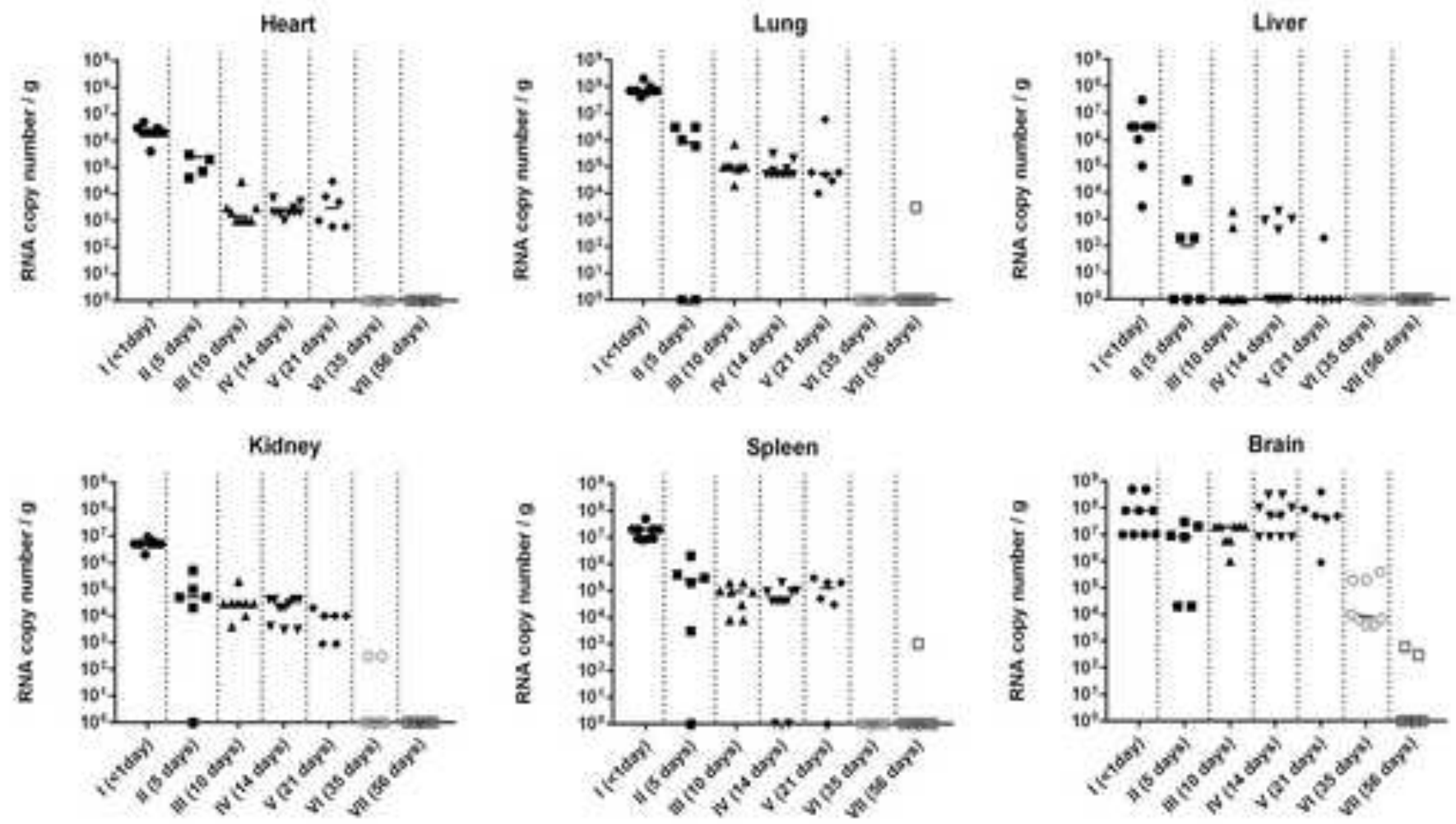

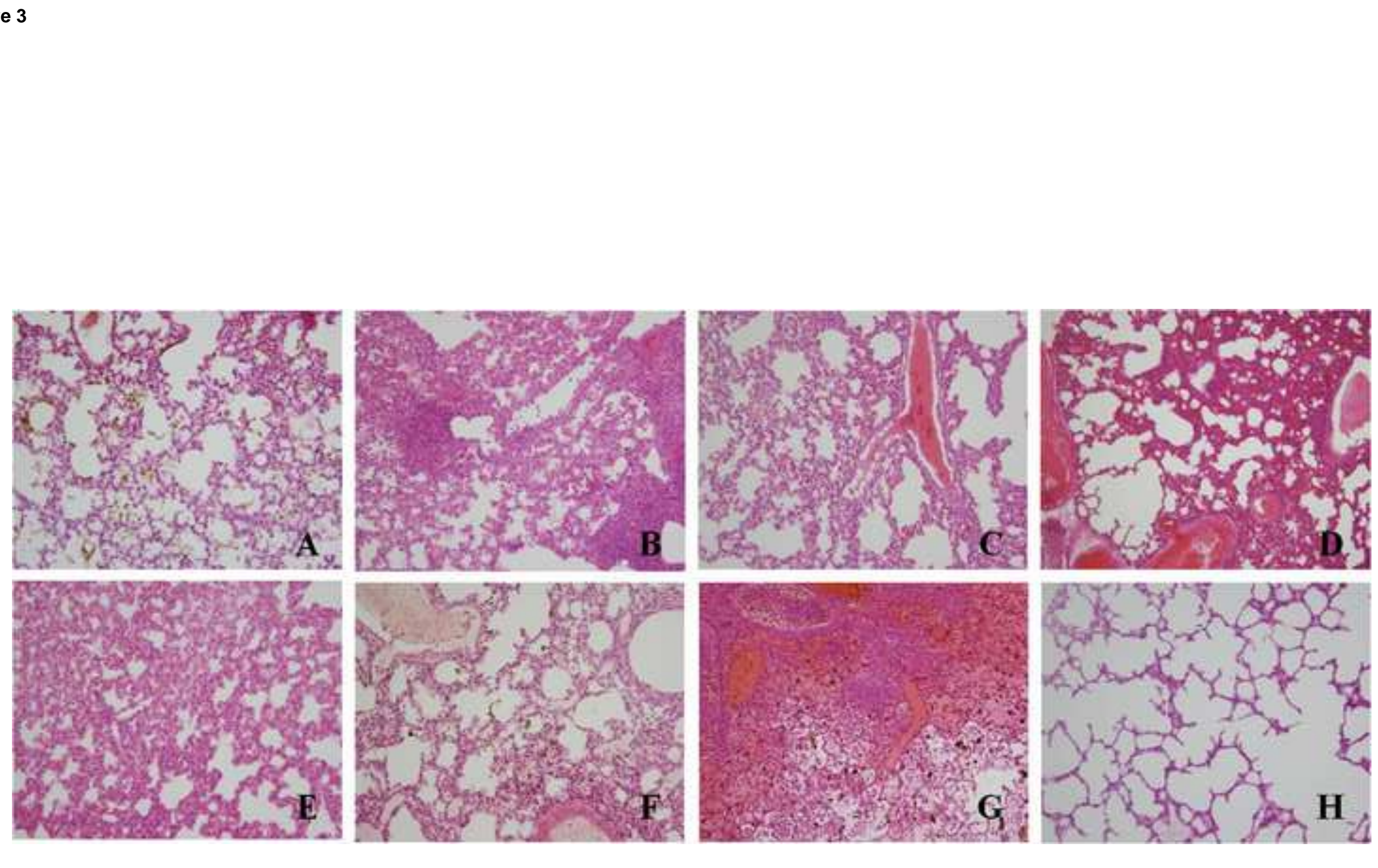

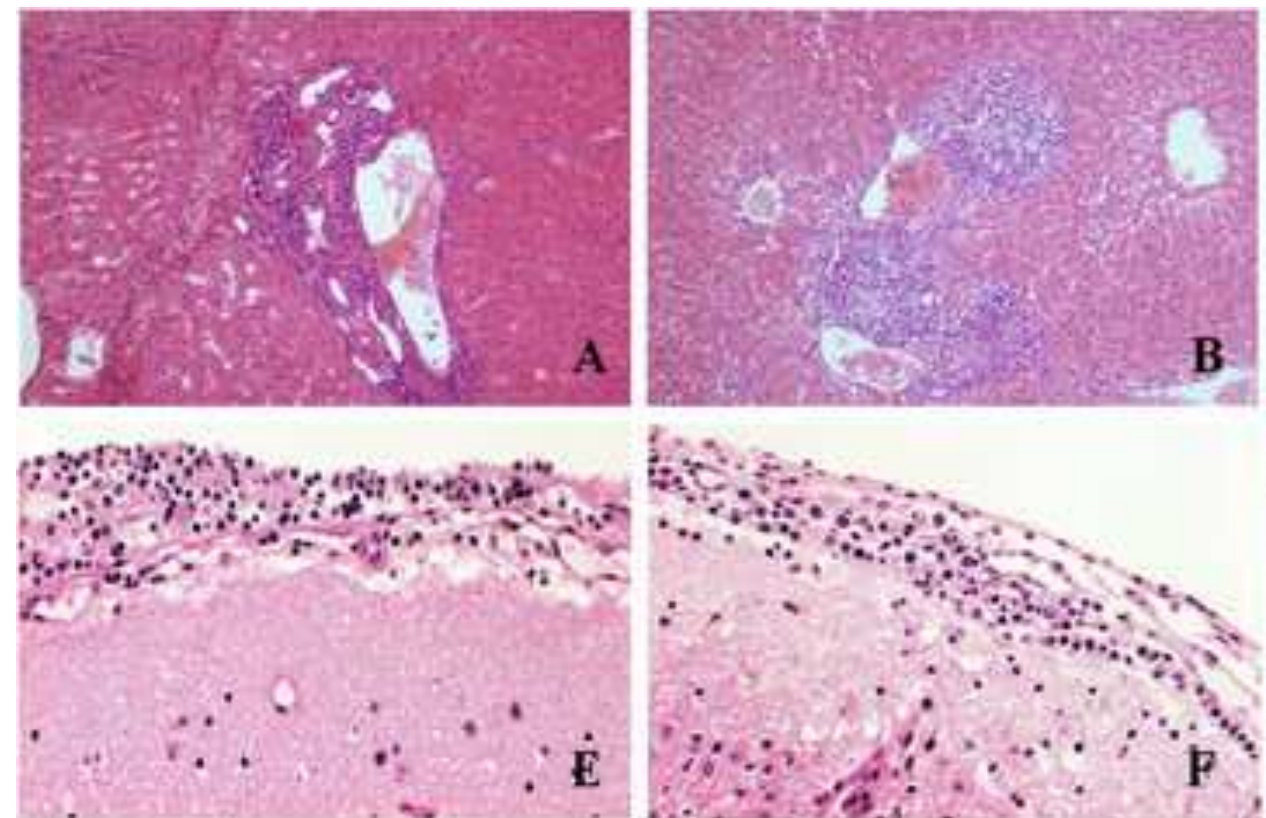
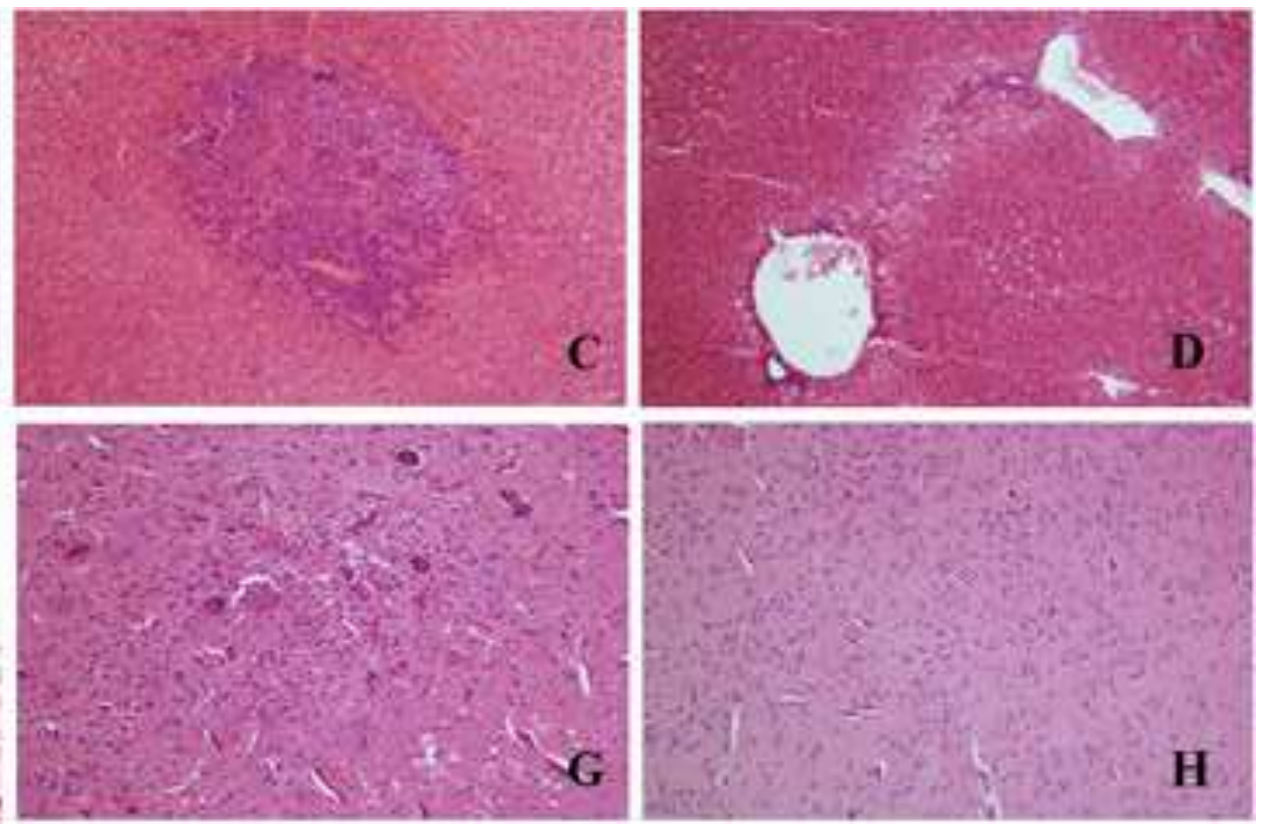

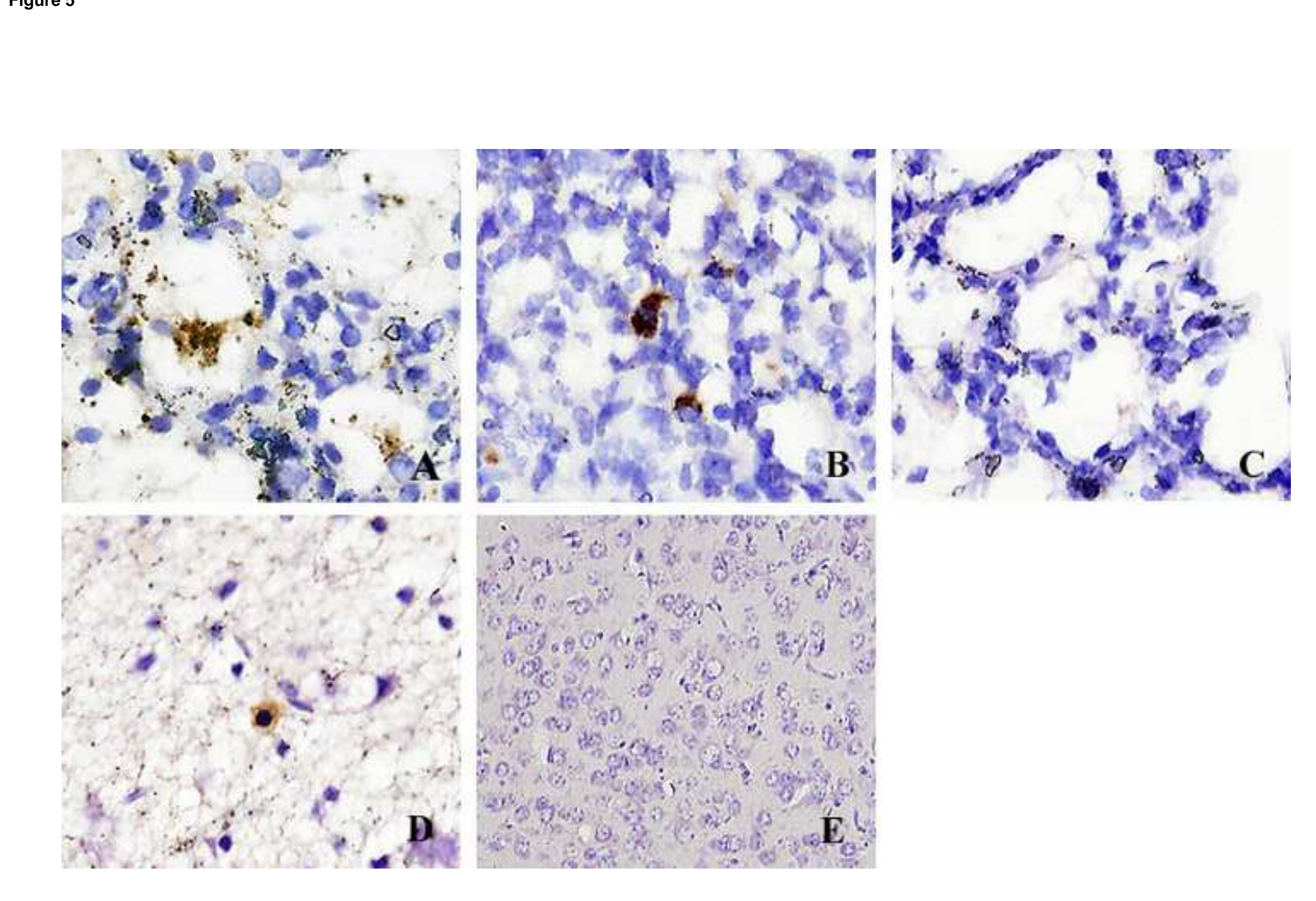

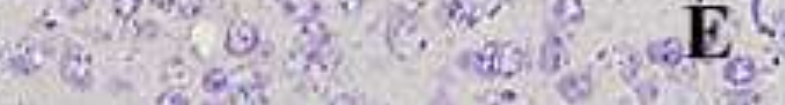

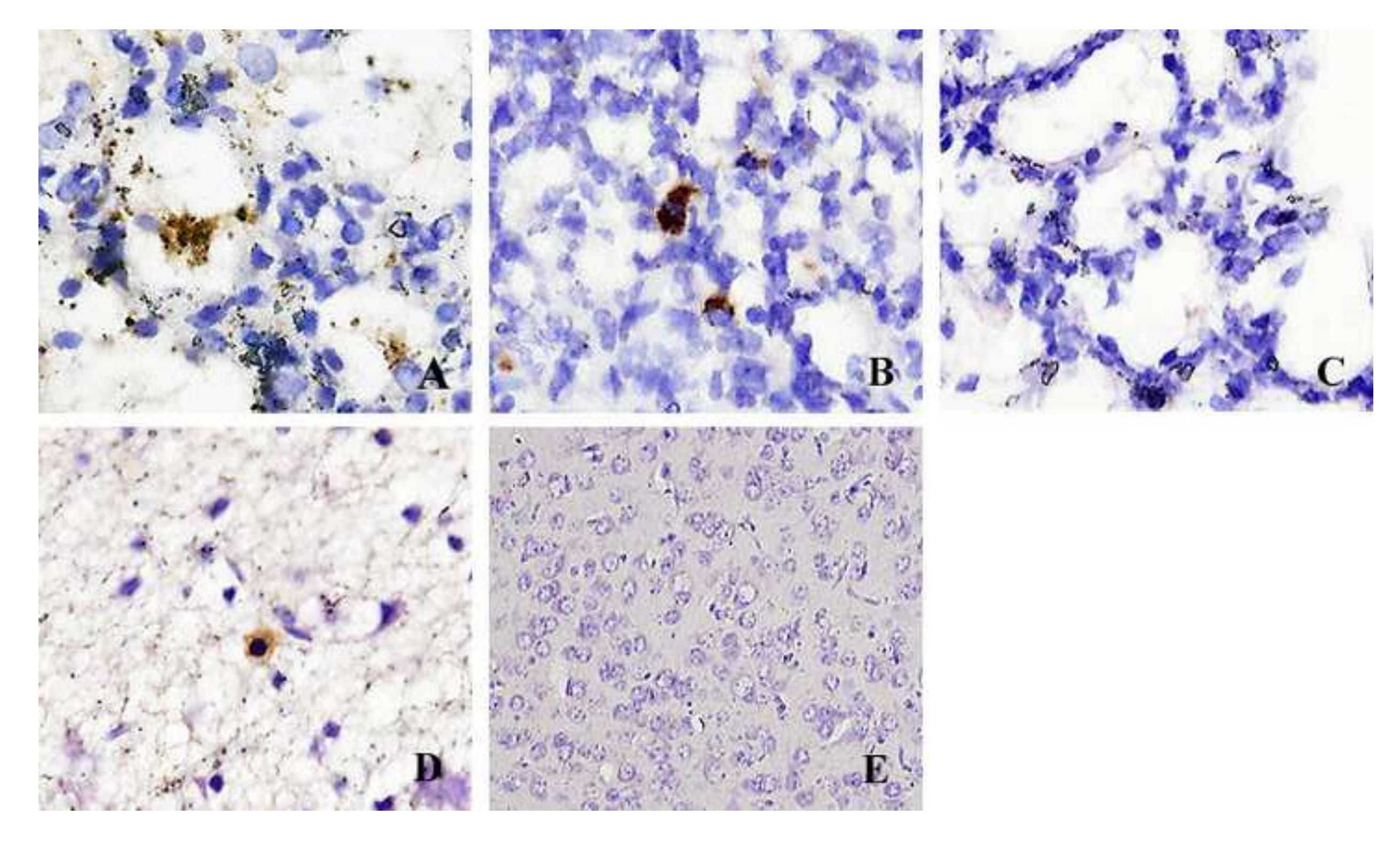

.

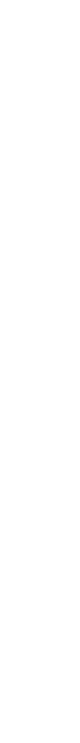

